\title{
Inter-annual Variability of March to May Rainfall over Tanzania and its Association with Atmospheric Circulation Anomalies
}

\author{
Philemon Henry King'uza ${ }^{A, B}$, Paul Tilwebwa Shelleph Limbu ${ }^{B}, C^{*}$ \\ Received: June 27, 2019 | Revised: September 11, 2019 | Accepted: September 20, 2019 \\ DOI: $10.5937 / g p 23-22430$
}

\begin{abstract}
This study used Empirical Orthogonal Function (EOF), student $t$ test, composite and correlation analysis techniques to investigate the inter-annual variability of March to May rainy season over Tanzania and its association atmospheric circulation anomalies. The EOF results showed that the rainfall over Tanzania during MAM season does not vary too much with the first dominant mode (EOF1) showing the variance of $22.4 \%$ of the total rainfall and that much of the rainfall being concentrated over the coast, northeastern and southern regions. It was found that during wet years, the study area was dominated by convergence at lower level which is associated with enough moisture advected by south easterlies from Indian Ocean due to the relaxation of Mascarene high $(\mathrm{MH})$ over the region and westerlies from Congo basin. The rising motion at lower level was enhanced with the presence of ascending limb of Walker circulation cell over the western Indian Ocean (WIO) and the coast region. Central Pacific and east coast of Atlantic Oceans are relatively warm during wet years. Furthermore, significantly negative correlation observed between southeast Indian Ocean (SEIO) region and MAM rainfall over Tanzania at the $95 \%$ confidence level portrays that much of the regions receive high sufficient amount of rainfall when the western Indian Ocean (WIO) is relatively warmer than the SEIO. The results show that Nino 3.4 and Tropical North Atlantic (TNA) indices are strongly positively correlated with MAM rainfall over the east coast region. This study will help to improve seasonal forecasts over Tanzania.
\end{abstract}

Keywords: Tanzania; Inter-annual Variability; Rainfall; EOF; MAM

\section{Introduction}

The variability of rainfall has shown a significant impact on disaster management efforts and growth of the economy of peasant people in sub-Saharan Africa countries (Wagesho \& Claire, 2016). Over East Africa, the abnormal events of atmospheric phenomena observed in recent years, were associated with late onset and early withdraw of MAM rainfall over the region (Mugalavai et al., 2008; Camberlin et al., 2009). Williams and Funk (2011) revealed that MAM rain- fall has a strong impact over East Africa in term of floods (drought) due to its high (less) intensity and amount compared to other rainfall seasons. Furthermore, they shown that the total rainfall amount and trend during MAM season is decreasing significantly. This leads to major climatic shock as it was discussed by Lyon and Dewitt (2012) since the economy of the East African region including Tanzania depends on rain fed agriculture (Katia et al., 2012).

\footnotetext{
A College of Atmospheric Sciences, Nanjing University of Information Science and Technology, Nanjing, Jiangsu, 21004, P. R. China

B Tanzania Meteorological Agency, P. O. Box 3056, Dar es Salaam, Tanzania

C Physics Department, University of Dar es Salaam, P. O. Box 35063, Dar es Salaam, Tanzania

* Corresponding author: Paul Tilwebwa Shelleph Limbu, email: paul.limbu@ymail.com
} 
Presence of the Congo basin, ITCZ and air-sea interaction phenomenon like East Africa tropical cyclone (TC), El Nino southern oscillation (ENSO), Indian Ocean dipole (IOD) and subtropical anticyclone such as St. Helena and Mascarene High have a great contribution to MAM rains variability over East Africa (Kabanda \& Jury, 1999; Camberlin \& Okoola, 2003). The same results were supported by (Black et al., 2003; Camberlin et al., 2009; Kijazi \& Reason, 2011) and (Mutai \& Ward, 2000; Gamoyo et al., 2015) when they also found that long rains and Short rains over the region are mainly controlled by movement of ITCZ. Rainfall in Tanzania is highly affected by subtropical quasi-permanent high-pressure belts (Tyson et al., 1996). Intensification of St. Helena and relaxation of Azores high promotes moisture influx from the Atlantic Ocean and the Congo Basin which influence rainfall in some parts of East Africa during the MAM season. Mascarene High drive south easterlies wind over the Indian Ocean, transport moisture flux to regions during long rain season (Manatsa et al., 2014). Moreover, the Congo air masses characterized by humid air are adverted towards the region which enhances convection and hence rainfall formation over the northwestern and western regions of Lake Victoria (Ntwali et al., 2016). Camberlin and Philippon (2002) identi- fied a weak positive relationship between East Africa MAM rainfall and eastern and central Pacific Ocean on the onset year of El Nino events and more pronounced negative anomalies in the decay phase of $\mathrm{El}$ Nino events. In addition, Lyon (2014) investigated the influence of ENSO to MAM rainy season over East Africa by focusing on March, April, and May separately and revealed a strong correlation between ENSO and March rainfall than in April or May.

Based on the previous studies which have been focused over the coastal region (Kabanda, 2018; Kabanda \& Jury, 1999; Zorita \& Tilya, 2002; Mapande \& Reason, 2005; Kijazi \& Reason, 2005, 2009, 2011), this study tends to cover the entire country by investigating the inter-annual variability of MAM rainfall and its associated atmospheric circulation by seeking the answers of the following questions; (i) How does the rainfall over the country varies from March to May (MAM) season from 1978 to 2017? (ii) How does the rainfall over Tanzania during MAM season responds to fluctuation of atmospheric systems? (iii) Is there any relationship between SST indices and MAM rainfall over Tanzania? The rest of the paper is organized as follows; section 2 is covering data and methodology used in the study, section 3 is discussing the results, and section 4 is about conclusion and recommendation.

\section{Data, study area and methodology}

\section{Study area}

Tanzania is the largest East African country bounded by latitudes of $12^{\circ} \mathrm{S}$ to $0.8^{\circ} \mathrm{S}$ and longitudes of $28^{\circ} \mathrm{E}$ to $41^{\circ} \mathrm{E}$ (Figure 1a). The country is characterized by high and Low land features such Mt. Kilimanjaro in the north east and Nile rift valley in the central way to southern part and the country is also surrounded by major water bodies like Lake Victoria, Lake Tanganyika, Lake Nyasa and Indian Ocean to the east which are having significant impacts on local weather systems and hence rainfall variability over the country (Manatsa et al., 2014). Tanzania is characterized by two rainfall regimes i.e. unimodal and bimodal regime due to north-south movement of Inter tropical convergence zone, ITCZ (Clark et al., 2003). The north, northeastern and eastern area experiences bimodal rainy seasons during October-December (short rainy, OND) and March-May (long rainy, MAM) while southwestern highlands, western and some parts of Lake Victoria experience unimodal rainfall pattern during October/November to April/May (Kabanda \& Jury, 1999; Mafuru \& Guirong, 2018).

\section{Data}

The study utilized monthly observation rainfall data of 20 scattered synoptic stations (Figure $1 \mathrm{~b}$ ) from the
Tanzania Meteorological Agency (TMA) for 40 years (1978-2017). The synoptic stations dataset used in this study represent eleven (11) homogeneous climatological zones in the country (Kijazi \& Reason, 2011; Mafuru \& Guirong, 2018). Despite that, precipitation gridded data set from the Climate Research Unit (CRU) version 4.02 (CRU TV v.4.02) with a resolution of $0.5^{\circ} \times 0.5^{\circ}$ from 1978 to 2017 was used in this study. The same dataset was initially used by Harris et al. (2014) for updated high-resolution grids of monthly climatic observations and recently the dataset was used by several scientists (Van Der Schrier et al., 2013; Koutsouris et al., 2015). However, gridded datasets parameters like Sea surface temperature (SST), wind components (zonal and meridional), velocity potential, air temperature, Omega, and stream function were obtained from NOAA website; Reanalysis (NCEP/NCAR) with a resolution of $2.5^{\circ}$ $\mathrm{x} 2.5^{\circ}$, the data details are documented by Kalnay et al. (1996) and the data covered the climatological period of 40 years (1978-2017). Reanalysis data sets were used to find; how the atmospheric circulation anomalies affect the MAM rainfall over the country and how they related to MAM rainfall.

The Oceanic SST indices i.e. Nino 3.4 index, DMI, TNA and TSA index were used for quantifying the 
(a) AFRICA

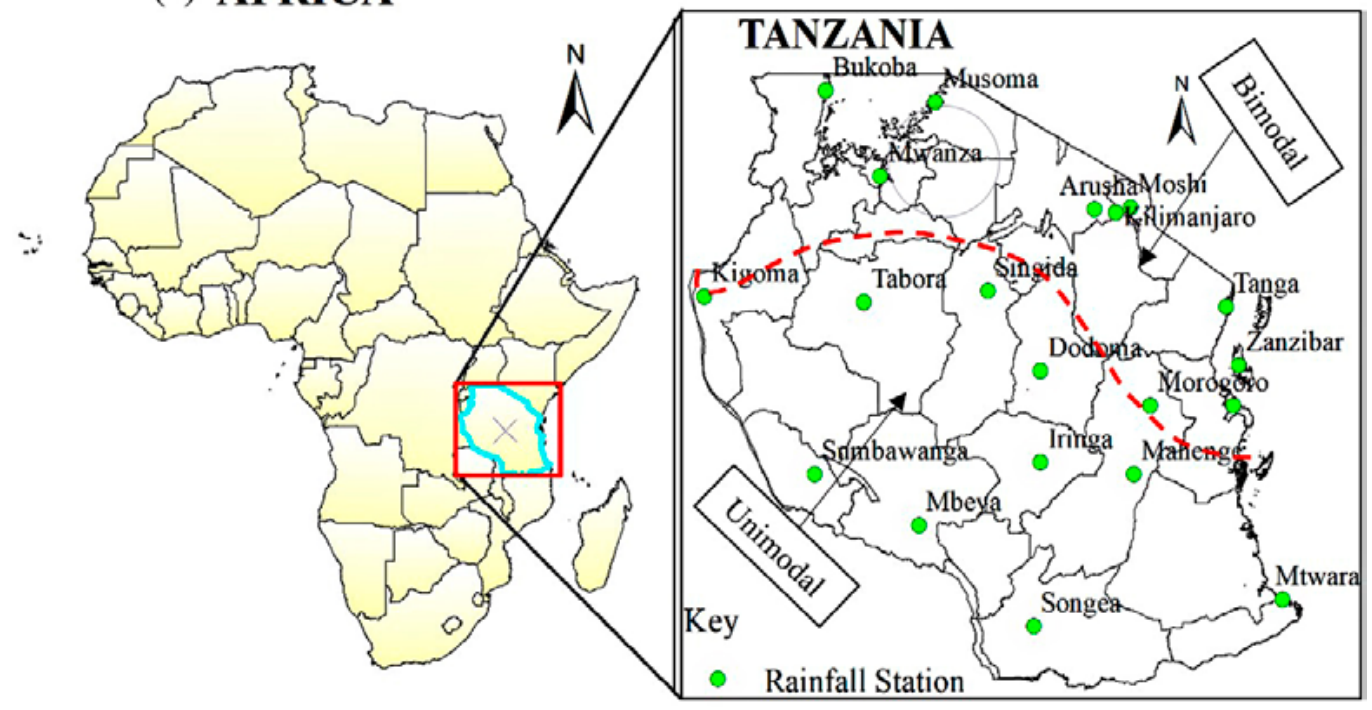

Figure 1. Location of the study area (a) Map of Africa marked with red box showing the location of Tanzania (b)Map of Tanzania showing the distributed rainfall stations used in the study. Dotted red line divides the regions of Bimodal and unimodal rainfall regime

correlation coefficient with MAM rainfall. DMI index defined as anomalous SST gradient between the western equatorial Indian Ocean $\left(50-70^{\circ} \mathrm{E}\right.$ and $10^{\circ} \mathrm{S}$ $-10^{\circ} \mathrm{N}$ ) and the southeastern equatorial Indian Ocean $\left(90-110^{\circ} \mathrm{E}\right.$ and $\left.10^{\circ} \mathrm{S}-\mathrm{O}^{\circ} \mathrm{N}\right)$ was fetched from https:// www.esrl.noaa.gov/psd/gcos_wgsp/Timeseries/Data/ dmi.long.data. $\mathrm{NINO}_{3.4}$ index which is calculated by taking the average sea surface temperature anomaly in the region bounded by $\left(5^{\circ} \mathrm{N}-5^{\circ} \mathrm{S}\right.$ and $\left.170^{\circ}-120^{\circ} \mathrm{W}\right)$ was obtained from https://www.esrl.noaa.gov/ psd/ data/correlation/nina34. data. TNA defined as an indicator of the Sea surface temperatures in the eastern tropical North Atlantic Ocean $\left(5.5^{\circ}-23.5^{\circ} \mathrm{N}\right.$ and $15^{\circ}-57.5^{\circ} \mathrm{W}$ ) and TSA as an indicator of the Sea surface temperatures in the eastern tropical South Atlantic Ocean $\left(0^{\circ}-20^{\circ} \mathrm{S}\right.$ and $\left.10^{\circ} \mathrm{E}-30^{\circ} \mathrm{W}\right)$ were taken from https://www.esrl.noaa.gov/psd/data/correlation/. All of these indices last for whole study period (1978-2017).

\section{Methodology}

Empirical Orthogonal Function (EOF) is the statistical method used to perform a matrix computation of a single variable and gives out eigenvectors and eigenvalues with physical meaning on spatial and temporal scale variability (Lorenz, 1956). The method depicts the variability of variable in spatial pattern (EOFs) which is consistent with oscillation in time interval (PCs) providing an amplitude of variability in a given time scale (Limbu \& Guirong, 2019). The first EOF corresponds to the leading eigenvalue of the covariance matrix having the largest variance in term of percentage and the second EOF corresponds to the second leading eigenvalue of the covariance matrix. The first principle component (PC) which is showing the magnitude of eigenvalue in time series corresponds to the first EOF and the second PC corresponds to the second EOF. The technique was used in this study to find the dominant modes with high rainfall variability during MAM season. The same techniques have been used by Krishnamurthy and Shukla (2000), Onyutha (2016), and Onyutha and Willems, 2016) to find the dominant modes of the intra-seasonal and inter-annual variations of the monsoon rainfall over East Africa.

Furthermore, based on the dominant mode of EOF, the study utilized the composite analysis method to investigate the atmospheric circulation systems which contribute to MAM rainfall variability over Tanzania during the wet and dry conditions. Wet and dry conditions were selected from the first PC with a standardized anomaly value of greater than or equal to +2 termed as wet years and standardized anomaly value of less than or equal to -2 as dry years. The same method in a region was used by Mutai and Ward (2000), Ogwang et al. (2012), and Koumare (2014). The method was tested by student $t$ test to find out whether the atmospheric systems such as winds, stream function, omega have a significant effect on rainfall variability over Tanzania. Pearson correlation analysis was used to test the linear relationship between MAM rainfall and tropical SST for 40 years. The existence relationship was tested by student $t$ test to find out whether the correlation was statistically significant enough to draw the conclusion that MAM rainfall over the country is possibly in- 
fluenced by large scale and mesoscale systems such as ENSO, IOD, TSA and TNA. This method was adopted from Dezfuli and Nicholson (2012) and Mutai and
Ward (2000) when they correlated the tropical sea surface temperature (SST) and rainfall over West Africa region and in East Africa respectively.

\section{Results and discussion}

\section{Classification of rainfall over Tanzania}

The rainfall of the country is dominated by two peak seasons i.e. MAM and OND as shown in Figure $2 \mathrm{a}$ for both observation and gridded datasets, which shows strong positive correlation coefficient $(r=0.96)$ between these two datasets. This gives the evidence of having bimodal rainfall regimes over a region in a year which supports the work done by Zorita and Tilya (2002). Even though both two seasons are known as a rainy season over the country, that is to say 'masika' for MAM rainfall and 'vuli' for OND rainfall, MAM season contribute high amount of rainfall by almost $43 \%$ of the total amount of rainfall that the country receives in a year (Figure $2 b$ ). During MAM season, high amounts of rainfall are concentrated over the coastal region, southern part, northern part, north eastern, and western part (Figure 3a). This is due to the presence of large water bodies over the northern part (Lake Victoria), western part (Lake Tanganyi$\mathrm{ka}$ ), and coastal region bounded by the Indian Ocean. Furthermore, high amount of rainfall observed over the southern and southwestern highlands are associated with the concurrence of Congo air mass boundary $(\mathrm{CAB})$ and ITCZ over those regions which influences rainfall over the country (Clark et al., 2003). Figure
3 b-d shows that rainfall is shifting northward from March to May due to northward movement of ITCZ. In March where the ITCZ is located in the south, the southern and western part receives high amount of rainfall than the other parts. The rainfall is concentrated over the coastal region, north and north eastern part in April and in May.

Spatial and temporal analysis of MAM rainy season over the country was further analyzed by using EOF method. The first three EOF modes accounts for 52.5\% of the total variance of rainfall over the country, this imply that rainfall over the country during MAM season does not vary too much during the study period. The first leading mode (EOF 1 ) shows $22.4 \%$ of the total variance characterized by positive loadings over the north eastern, coast region, southern and western regions, and negative loadings over the north, north western and central regions (Figure 4a). Areas of positive (negative) loading indicate the presence of high (less) amount of rainfall. EOF 2 and EOF 3 accounts for $16.8 \%$ and $13.3 \%$ of the total variance of rainfall, respectively. Corresponding to EOF 1 , the time series of first leading mode (PC 1) shows the inter-annual and inter-decadal variations of rainfall for the whole study period (Figure 4b) which describes that rainfall during MAM season is

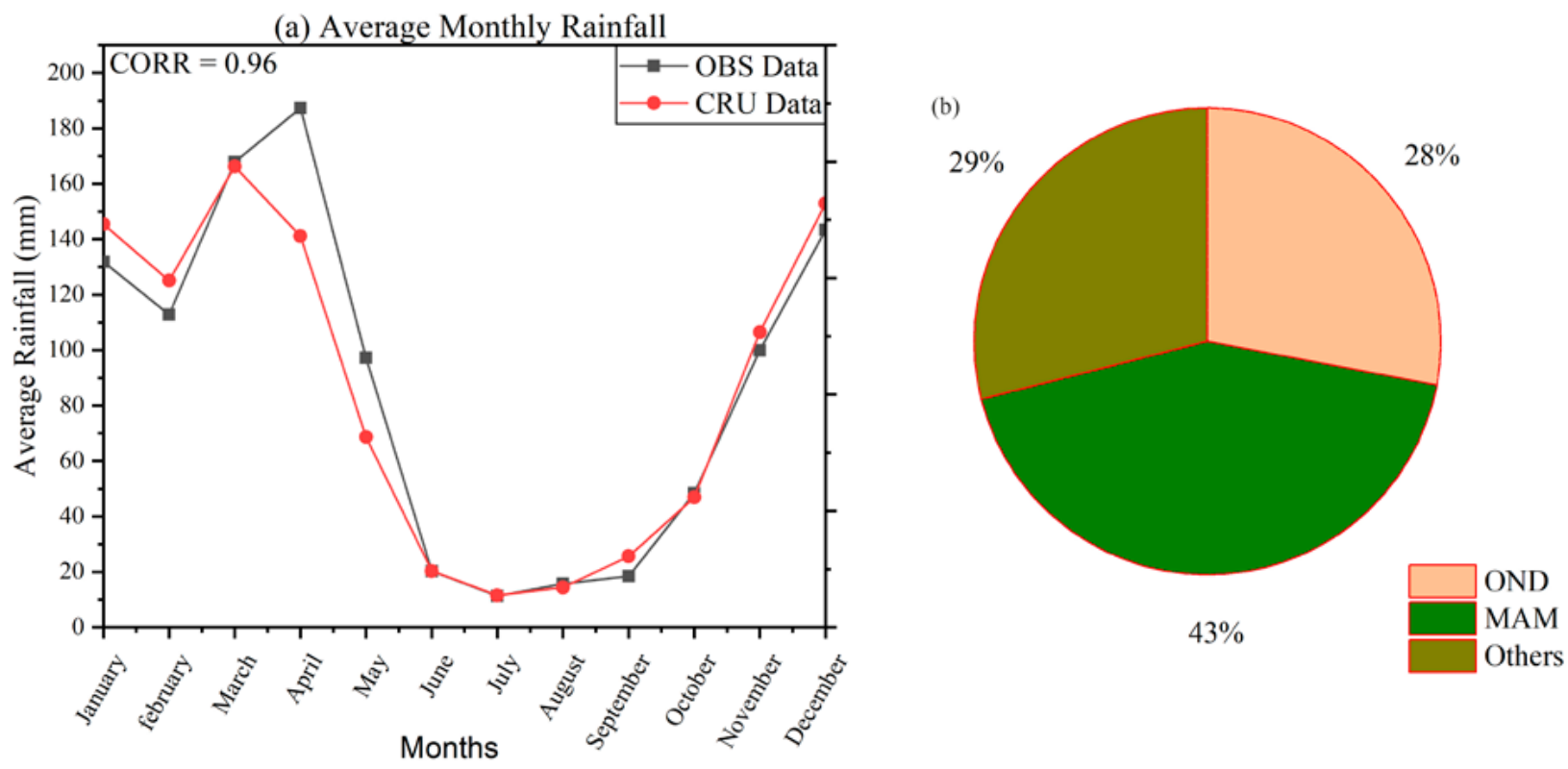

Figure 2. (a) The Annual cycle of rainfall ( $\mathrm{mm}$ ) over Tanzania for observation and gridded datasets. A significant correlation of 0.96 at the $99 \%$ confidence level is observed; (b) Contribution of season rainfall in percentage over the country from 1978-2017 

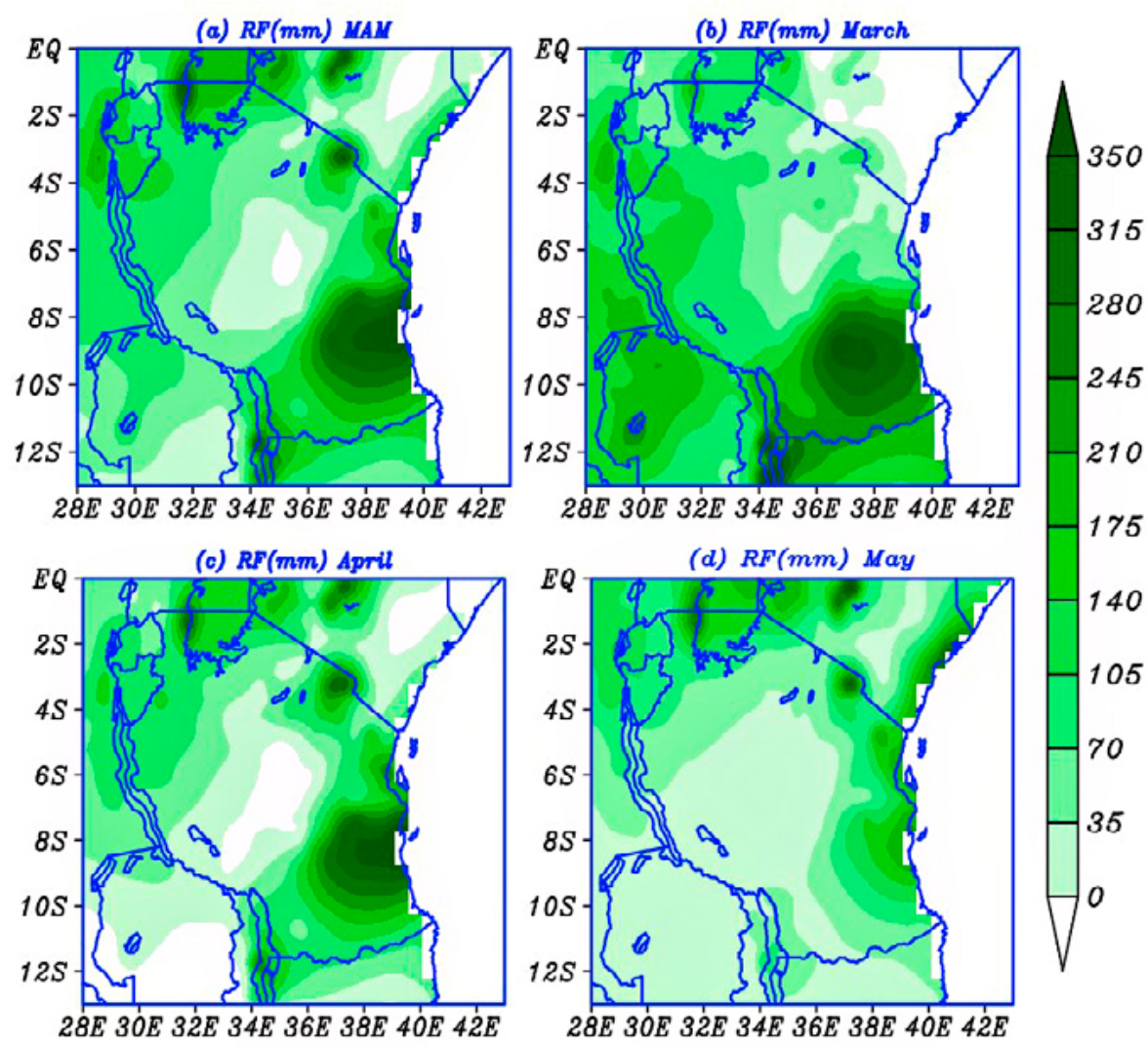

Figure 3. Spatial climatology of rainfall (mm) from 1978 to 2017 for (a) March to May (MAM) rainfall; (b) March rainfall; (c) April rainfall; and (d) May rainfall

influenced by atmospheric systems which varies interannually such as IOD and ENSO and in inter-decadal way such as Pacific decadal oscillation, PDO (Dezfuly \& Nicholson, 2012). $\mathrm{PC}_{1}$ as the time series of the dominant mode was detrended to find the wet and dry years which fits in the inter-annual variations. Based on the standardized anomaly with amplitude of $\geq+2$ or $\leq-2$, wet and dry years were identified and used for composite analysis. Both $\mathrm{PC}_{2}$ and $\mathrm{PC}_{3}$ shows that after a year of 2000, the time series were charactrized by inter-decadal variations this is probably due to climate change occured over the region. 

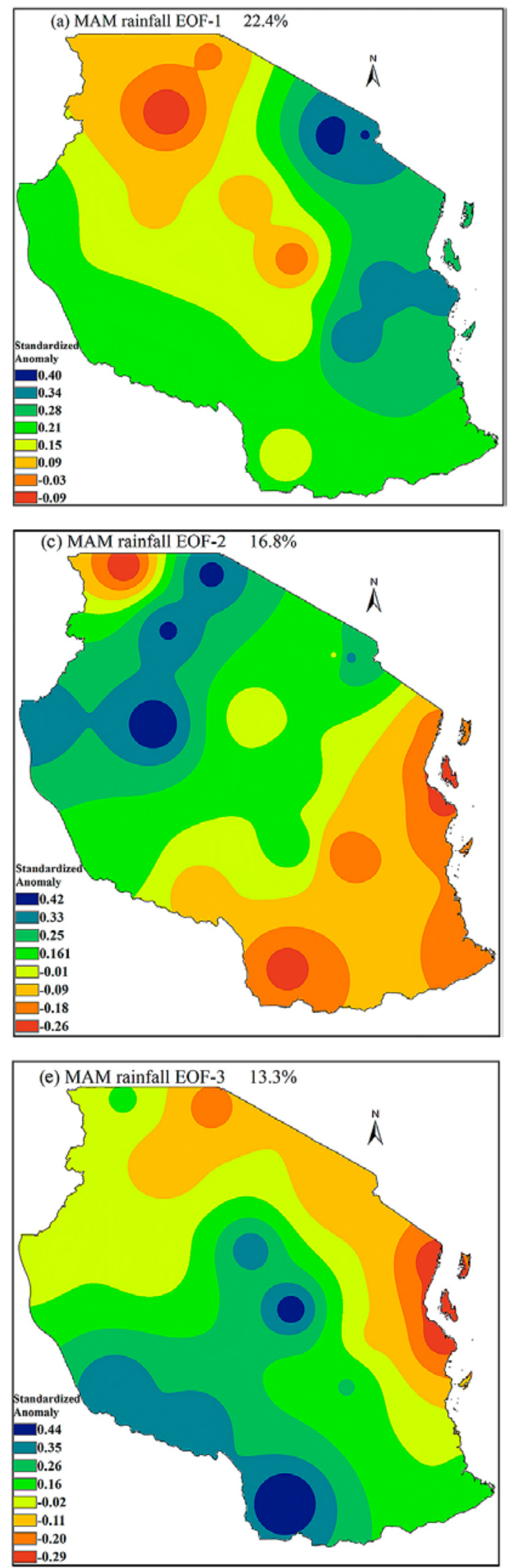

(b) MAM rainfall $\mathrm{PCl}$

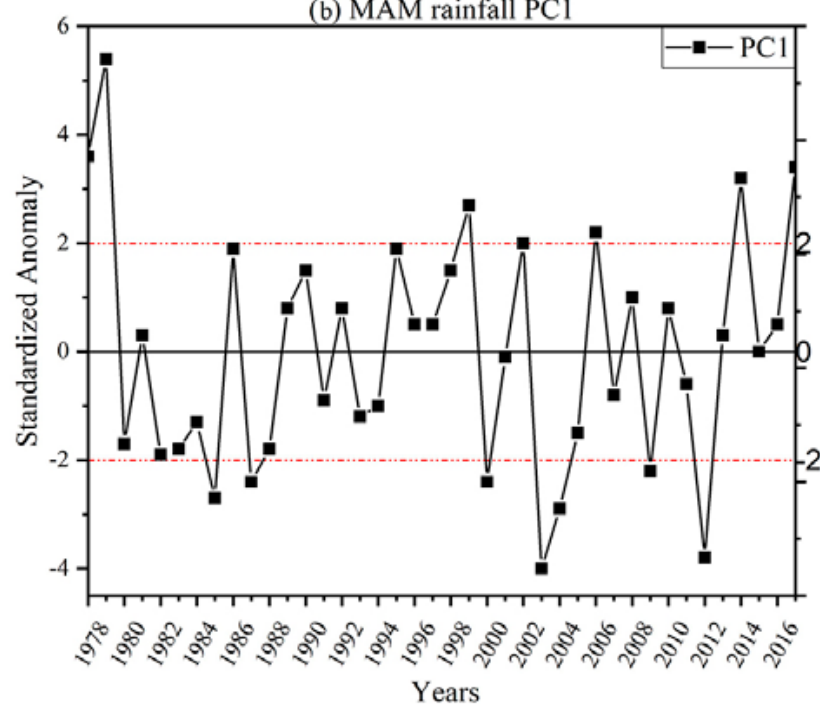

(d) MAM rainfall PC2

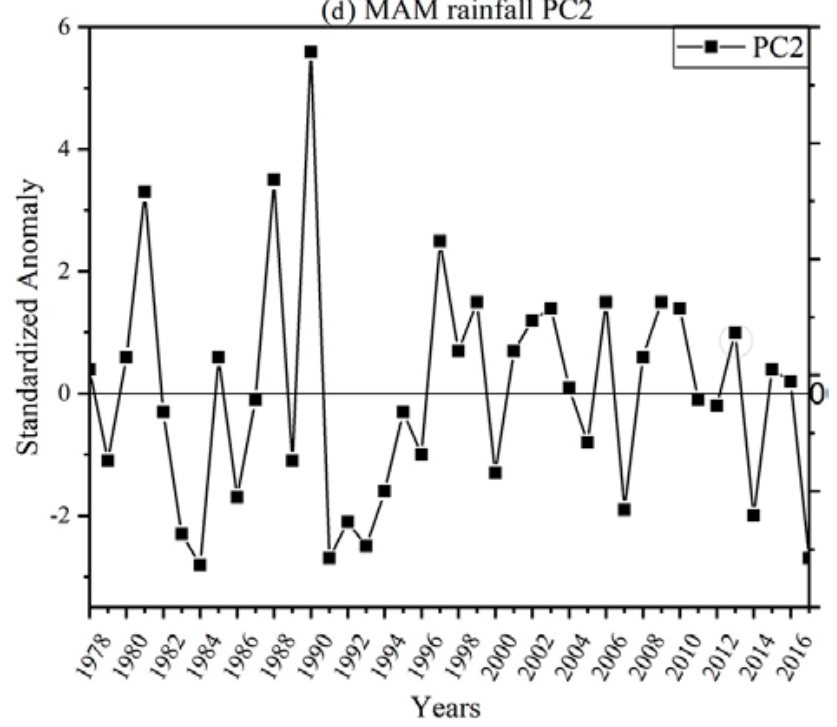

(f) MAM rainfall PC3

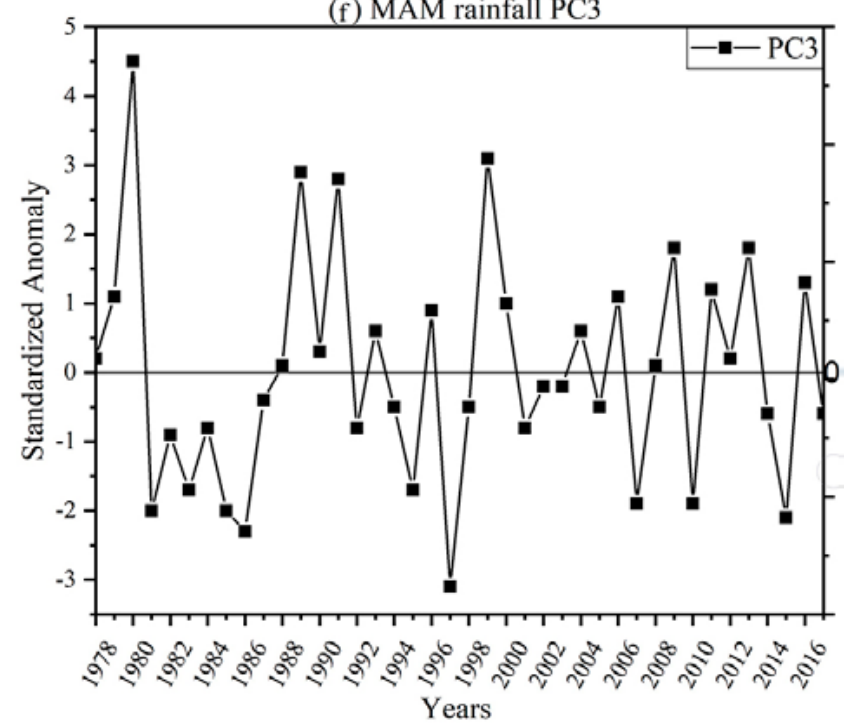

Figure 4. Spatial patterns of (a) the first EOF mode showing $22.4 \%$ of variance; (b) Time series of the first EOF (PC 1) mode (c) the second EOF mode showing $16.8 \%$ of the variance; (d) Time series of the second EOF (PC 2) mode; (e) the third EOF mode showing $13.3 \%$ of Variance $(f)$ Time series of the third EOF (PC 3 ) and their amplitudes are normalized by the standard deviation 


\section{Atmospheric circulation anomalies} on rainfall variability over Tanzania

Composite analysis method used 7 wet years (1978, 1979, 1999, 2002, 2006, 2014 and 2017) and 7 dry years $(1985,1987,2000,2003,2004,2009$ and 2012) from the first time series of the dominant mode ( $\mathrm{PC} 1)$ to assess the circulation systems related to wet and dry conditions. Figure $5 \mathrm{a}$ and $\mathrm{b}$ shows the composite analysis of wind anomalies during wet and dry years at 850 $\mathrm{hPa}$. It displays that during wet years, westerly winds carying moist air from Congo basin and southeasterly winds advecting moist air from southwest Indian Ocean (SWIO) converge over the country, resulting to ascending air at the lower level which is supported by Kijazi and Reason (2005) and Manatsa et al. (2014). The convergence system observed over the country is statistically significant at the $95 \%$ confidence level due to the significant low pressure system observed over the SWIO and relaxation of Mascarene high $(\mathrm{MH})$ over the coast of Madagascar (Figure 5a). The convergence systems seen over the south of Tanzania was due to convergence of continental air from Namibia due to the presence of high pressure system over the region and maritime air from the Indian Ocean. Additionally, it was revealed that St. Hellena was relaxed moving southward during wet years and it was intensified towards the continent during dry years (Figure 5b). During dry years, $\mathrm{MH}$ intensify and hinder the moist air advected towards the region. Figure $5 \mathrm{C}$ shows that at $850 \mathrm{hPa}$ the study region is significantly dominated by convergence winds at the $95 \%$ confidence level which is consistence with positive velocity potential anomalies over the same region and western Indian Ocean (WIO). The positive (negative) velocity potential anomalies observed over the country and WIO (eastern Indian Ocean, EIO) indicates the ascending (desceding) motion over these regions. At upper level $(200 \mathrm{hPa}$ ) during wet years (Figure $5 \mathrm{~d}$ ), the

(a)MAM Wind (Wet years) at 850hpa

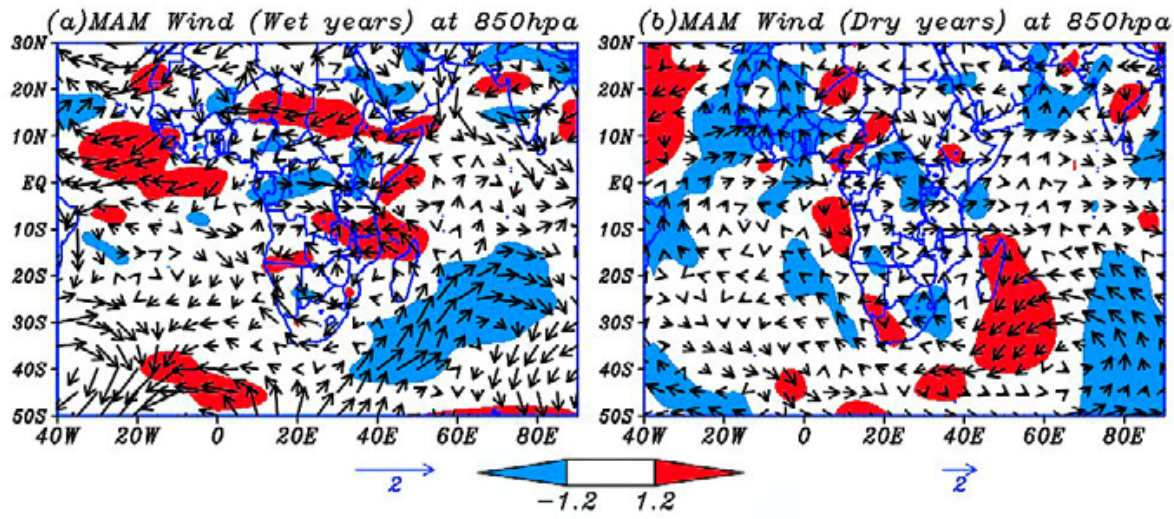

(c) MAM-V.P (Wet years) at $850 h P a$

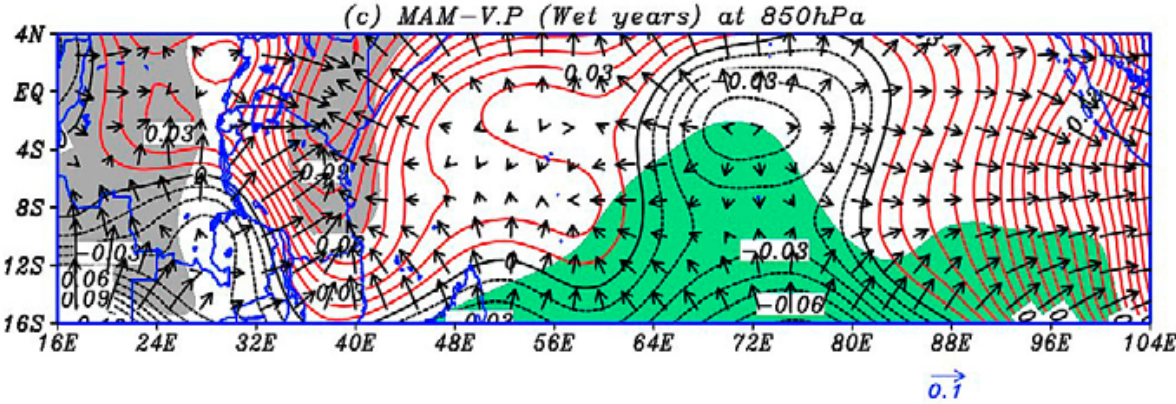

(d) $M A M-V . P$ (Wet years) at $200 \mathrm{hPa}$

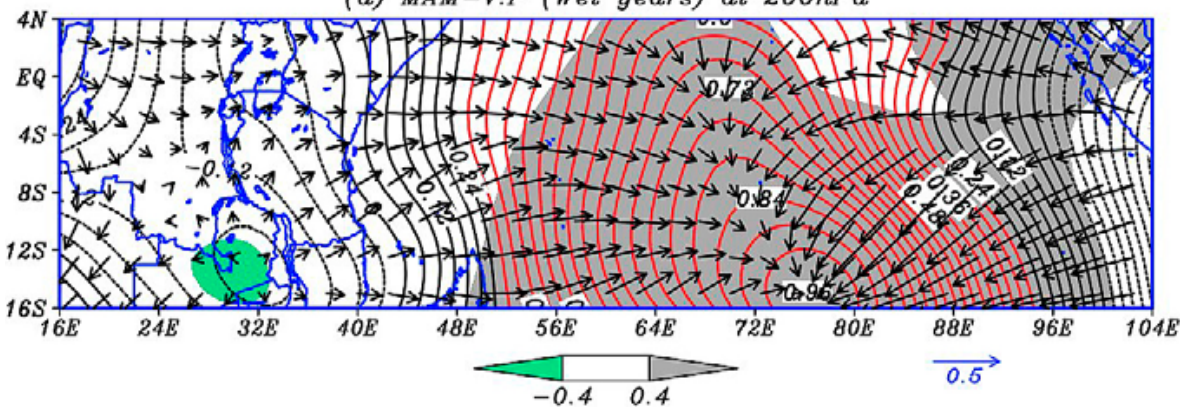

Figure 5. Composites of MAM wind anomalies (vector, $\mathrm{ms}^{-1}$ ) at $850 \mathrm{hPa}$ for (a) wet years (b) dry years; Anomalous MAM divergent winds (vector, $\left.\mathrm{ms}^{-1}\right)$ and velocity potential in contour $\left(10^{6} \mathrm{~m}^{2} \mathrm{~s}^{-1}\right)$ during wet years at (c) $850 \mathrm{hPa}$ and (d) 200 hPa from 1978 to 2017 . The shaded areas are representing significant regions at the $95 \%$ confidence level 
study area and WIO are dominated by divergence systems and descending motions which proves the presence of strong convective activities at the lower level. The Ascending (descending) motion observed over the WIO (EIO) defined the so called Walker circulation cell over Indian Ocean which is moving westward and brings moist air towards the coasta region and hence strong convective activities occurred over the region giving the same results as the one discussed by Limbu \& Guirong (2019) in their work of inverstigating the influence of Walker circulation cell over Indian Ocean to rainfall veriability in Tanzania.

Furthermore, the study investigated that, the study region especially the coast, north east and the area around Lake victoria during wet years (Figure 6a)

(a) MAM M.T (Wet years) at $850 \mathrm{hpa}$

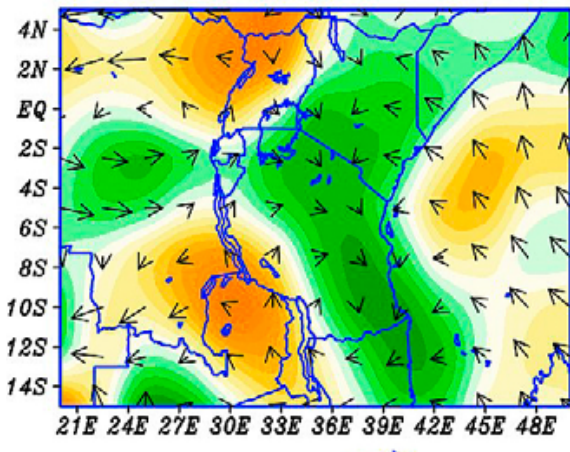

have enough moistures driven by westerly winds from Congo basin and from Indian Ocean favourable for rainfall formation. The amount of moisture seems to be more and enough for rainfall formation due to the presence of large water bodies over the region and the presence of Indian Ocean to the east. These areas are associated with convergence winds which results updraft and hence rainfall formation over the country. During dry years (Figure 6b), the coast region is domonated by dry and stable air and winds are westerlies. To support this observation, Figure $6 \mathrm{c}$ and $6 \mathrm{~d}$ shows that the cross-section of vertical velocity from lover level to upper level during wet years over the southern are characterized by rising motion and the coast regions during dry years are characterized

(b) MAM M.T (Dry years) at $850 \mathrm{hpa}$
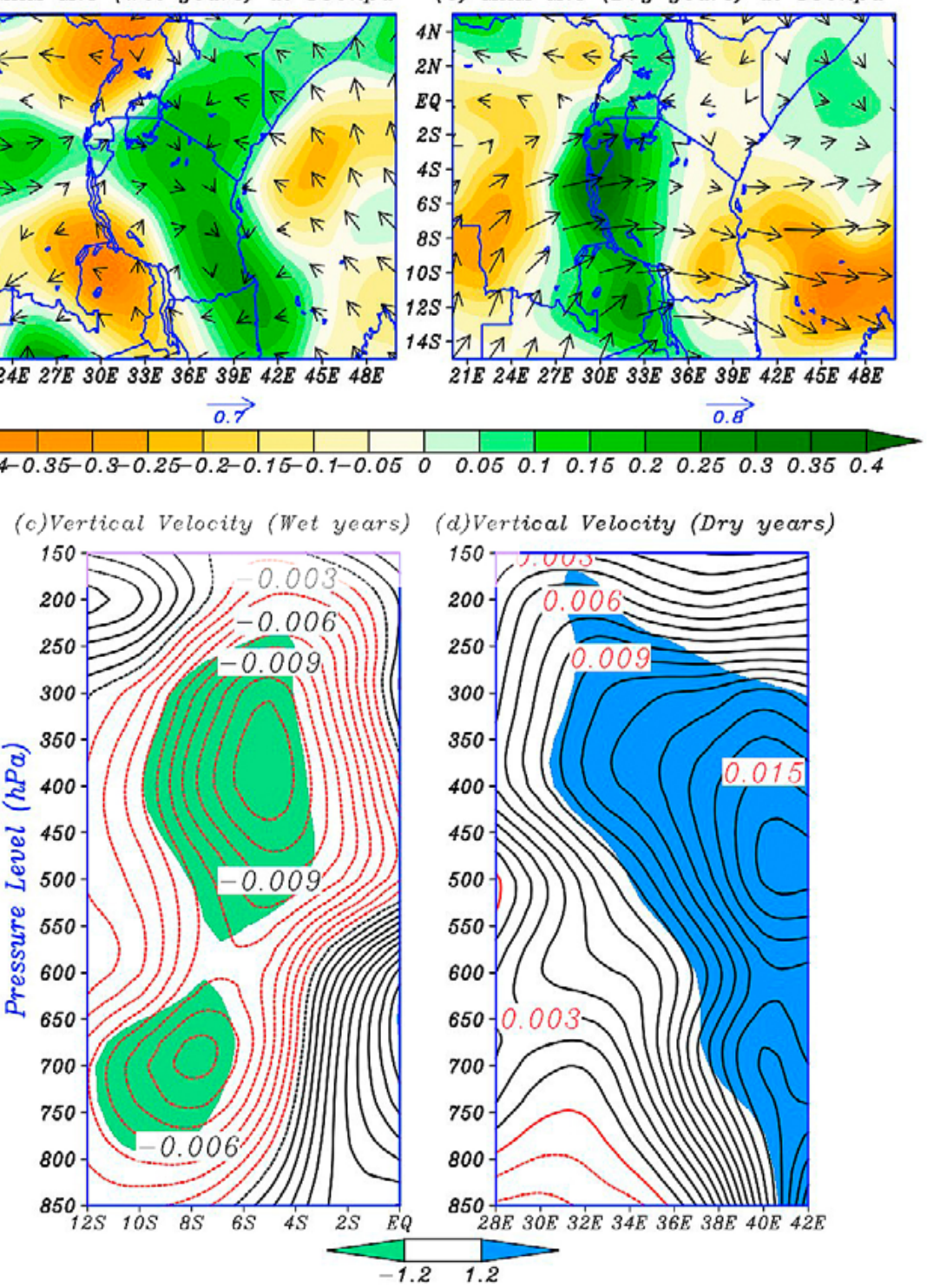

Figure 6. Composite of moisture transport (MTR) anomalies at $850 \mathrm{hPa}$ in $\mathrm{g} \mathrm{kg}^{-1} \mathrm{~ms}^{-1}$ over the period 1978 -2017 in (a) wet years and (b) dry years. Vectors indicate water vapor transport, whereas shaded moisture convergence (divergence) is shaded with positive (negative) anomaly; Cross-section of pressure vertical velocity $\left(\mathrm{ms}^{-1}\right)$ anomalies averaged over fixed (c) longitude of between $280 \mathrm{E}$ and $420 \mathrm{E}$ (d) latitude of $12^{\circ} \mathrm{S}$ and $0^{\circ}$. Positive (negative) values indicate areas of rising (sinking) motion. Shaded areas (blue and green in color) signify the significant regions at t-test based on $95 \%$ confidence interval 
(a) MAM SF climatology (850hPa)

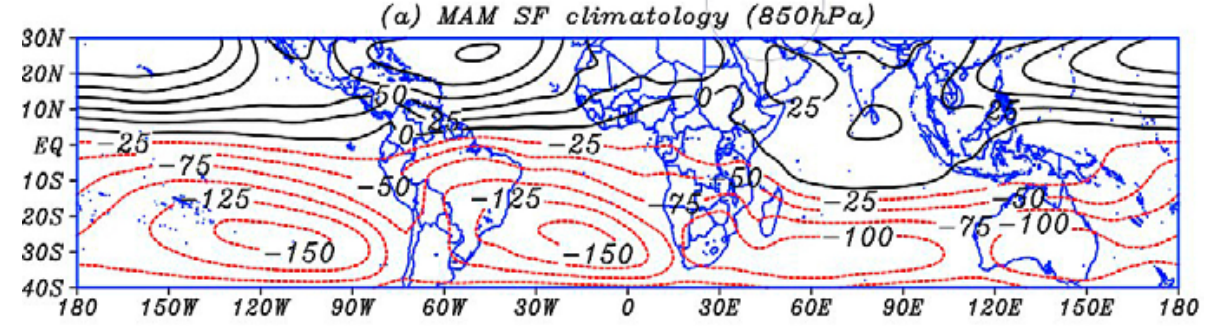

(b) SST (Wet Years)

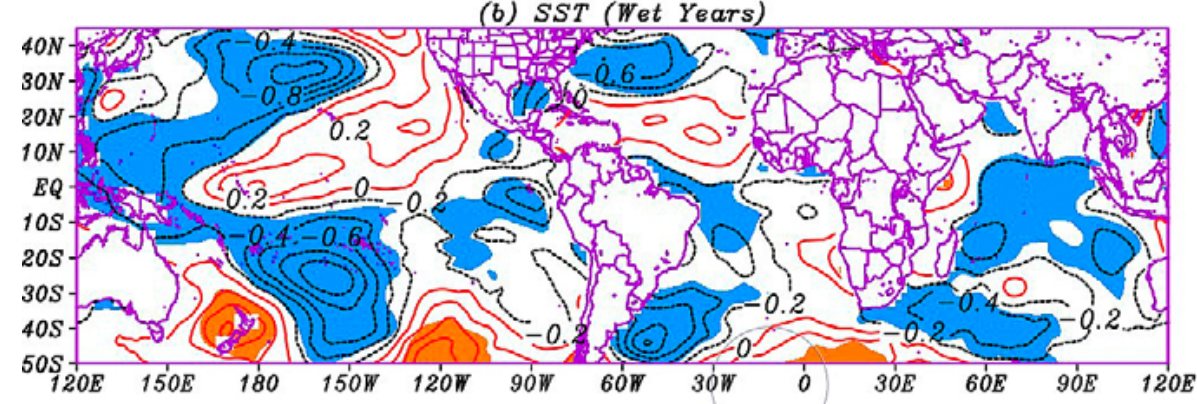

(c) SST (Dry Years)

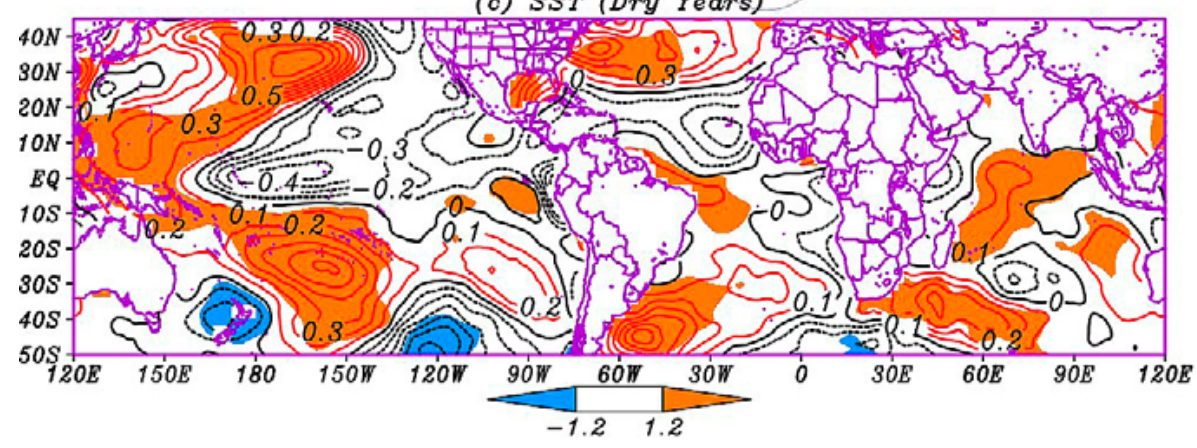

Figure 7. (a) Climatology of stream function during MAM season from $1978-2017$ in contour $\left(1^{*} 10^{-5} \mathrm{kgs}^{-1}\right)$ at $850 \mathrm{hPa}$; Composite of sea surface temperature $(\mathrm{oC})$ anomalies during (b) wet years and (c) dry years. Shaded areas signify the significant regions at $\mathrm{t}$-test based on $95 \%$ confidence interval

by sinking motion which imply that during the wet years (not shown in this papar) the areas were characterized by rising motion. The presence of overlaying positive vertical velocity at the upper level (300-150 $\mathrm{hPa}$ ) in the south (Figure $6 \mathrm{c}$ ), indicates the formation of cloud and hence rainfall formation.

The climatology of stream function at the lower level $(850 \mathrm{hPa})$ shows the teleconection between Pacific, Atlantic and Indian Oceans. It shows how well Pacific and Atlantic Ocean patterns are connected in MAM season having almost the same magnitude (Figure $7 \mathrm{a}$ ). The presence of troughs in the subtropical regions over the Pacific and Atlantic Ocean, attracts attention to further investigation wether these two Oceans influence the rainfall during the MAM season. The composite of SST anomalies during wet years (Figure $7 \mathrm{~b}$ ) show a positive (warm) SST anomalies in the central equatorial Pacific Ocean and negative (cool) SST anomalies in the subtropical Pacific Ocean in both hemispheres. There is a slightly positive (warm) SSTs in the WIO and along the coast of Africa in the Atlanric Ocean and negative (cool) SST anomalies over the EIO and along the coast of south America continent. The opposite sign was seen during the dry years (Figure $7 \mathrm{c}$ ). This shows that Pacific, Atlantic and Indian Oceans behaves differently in different atmospheric key conditions (i.e. wet and dry years) illustrating the influence of these Oceans on rainfall variability of Tanzania.

\section{Relationship between SST and MAM rainfall anomalies over Tanzania}

As it is shown in Figure $7 \mathrm{~b}$ and $\mathrm{c}$ that SSTs anomaly responds differently during the wet and dry years, this led us to investigate whether there is an existing relationship between SST anomalies and MAM arainfall over Tanzania. The spatial map of correlation between MAM rainfall and SST anomalies over the Oceans (Figure 8b) shows significantly positive correlation at the $95 \%$ confidence level over the El Nino regions and significantly negative correlation along the maritime continent, tropical Atlantic Ocean and subtropical Pacific Ocean. The regions of influence over the Oceans were well captured when the PC1 time series was correlated with SSTs (Figure $8 \mathrm{c}$ ). This potrays the presence of dipole like structure over Indian Ocean with significantly negative correation over the south EIO 
(SEIO) and slightly positive correlation over the WIO along the coast region of East Africa. A region of positive correlation over the central Pacifc Ocean is well captured compared to that of Figure 8b. Time correlation between the avearge MAM rainfall for the whole study period and $\mathrm{PC} 1$ from the EOF dominant mode give a strong positive correlation coefficient $(\mathrm{r}=0.9)$ at the $99 \%$ confidence level (Figure 8 a).

We used Figure $8 \mathrm{c}$ to mark the regions which probably influence MAM rainfall varibility over the coun-

(a) CORR of MAM Rainfall and PC1

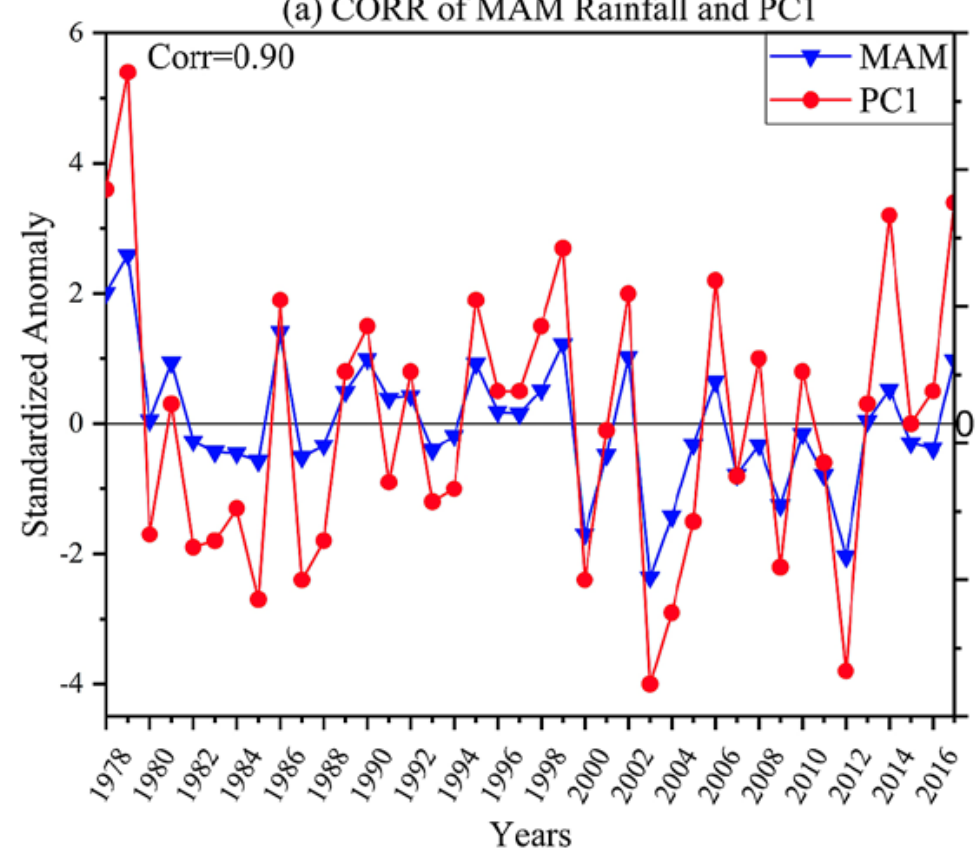

(b) MAM CORR of Rainfall \& SST

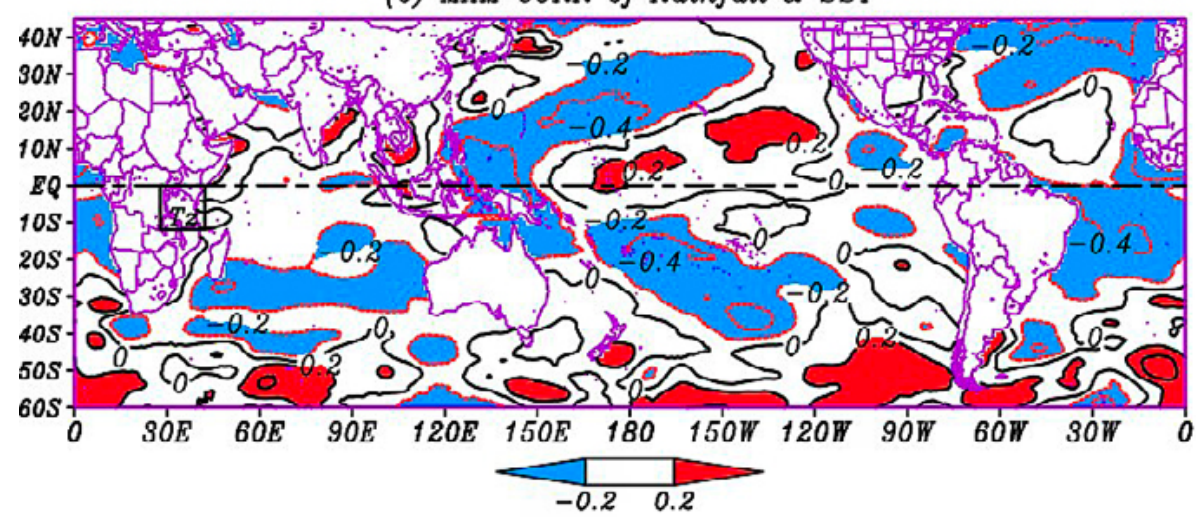

(c) MAM CORR of PC1 \& SST

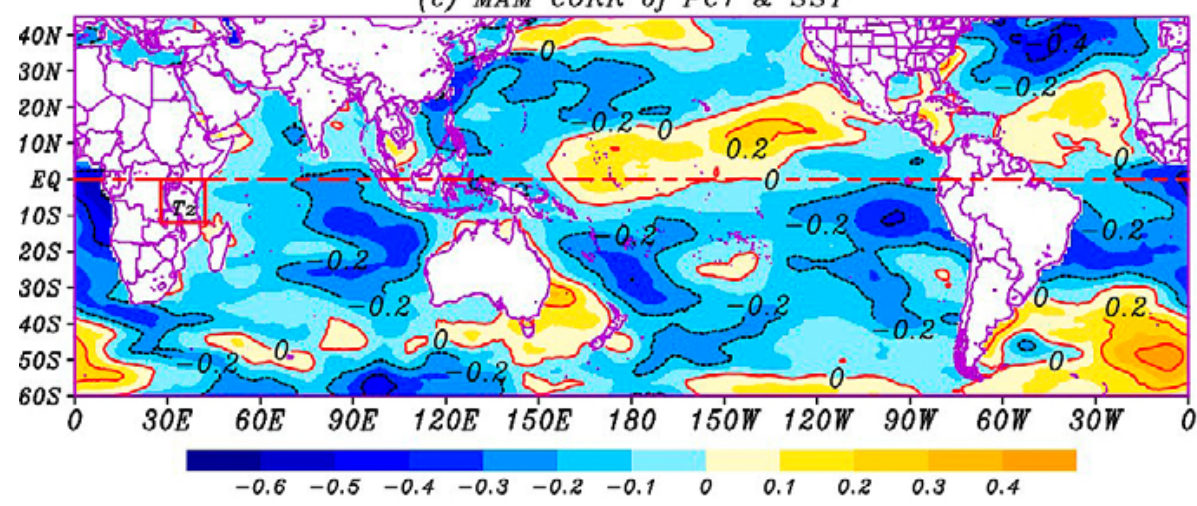

Figure 8. (a) Time correlation between the observed MAM rainfall over Tanzania and the time series of the first leading EOF mode (PC 1) from 1978 to 2017. A significant correlation coefficient of 0.9 at the $99 \%$ confidence level is observed; Spatial map of correlation between SST anomalies and (b) MAM rainfall (c) time series of the first leading EOF mode (PC 1) over the Oceans. Shaded regions are significant at the $95 \%$ confidence level 
try i.e. $\mathrm{A}\left(\mathrm{O}^{\mathrm{o}}-2 \mathrm{O}^{\circ} \mathrm{E}, 15^{\mathrm{o}} \mathrm{S}-\mathrm{O}^{\circ}\right), \mathrm{B}\left(41^{\circ}-45^{\circ} \mathrm{E}, 10^{\circ} \mathrm{S}-\mathrm{O}^{\circ}\right)$, $\mathrm{C}\left(85^{\circ}-110^{\circ} \mathrm{E}, 30^{\circ} \mathrm{S}-10^{\circ} \mathrm{S}\right)$, and $\mathrm{D}\left(190^{\circ}-240^{\circ} \mathrm{E}, 5^{\circ} \mathrm{S}-5^{\circ} \mathrm{N}\right)$. It was shown that the correlation between region $\mathrm{A}$ and $\mathrm{PC}_{1}$ is statistically weak and not signficant $(\mathrm{r}=-$ o.13) at the $95 \%$ confidence level. The correlation between region $\mathrm{B}$ was also very weak $(\mathrm{r}=-0.1)$ and that of region $C$ (Figure 9a) was significantly negative $(r=-$ o.3). The correlation in region $\mathrm{D}$ was weak $(\mathrm{r}=-0.1)$. The dipole pattern in Indian Ocean (difference between region $\mathrm{B}$ and $\mathrm{C}$ ) gives a strong and significant correlation of $r=0.2$ (Figure $9 b$ ) meaning that the study region receives rainfall over the country when the WIO is relatively warm. And the significant negative correlation coefficients obtained in region $\mathrm{C}$ illustrates that this region influence the rainfall over the country. The spatial map of correlation between region $\mathrm{C}$ and MAM rainfall over Tanzania (Figure 9c) shows that the central part of country is dominated by posi- tive correlation while the rest parts of the country are negatively correlated with region $\mathrm{C}$. The difference between region $\mathrm{B}$ and $\mathrm{C}$ (region $\mathrm{B}-\mathrm{C}$ ) shows a positive correlation along the coast, Lake Zone basin and the southwestern part while the other parts are negatively correlated (Figure 9d). This explains that when the WIO is relatively warmer than the SEIO, the coast regions are positively correlated with rainfall.

Morever, the study used the well known SST indices such as DMI, Nino 3.4, TNA, and TSA to find out how and in what magnitude they are correlated to PC1. The analysis found that the correlation coefficients between Nino 3.4 (DMI) and $\mathrm{PC}_{1}$ are -0.05 (-0.15) and the correlation between TNA (TSA) and $\mathrm{PC} 1$ is $0.05(-0.14)$. These coefficients seems to be not significant but they have got an influence on rainfall variability over the country. Figure 10a shows that all over the country, DMI is correlated negative-
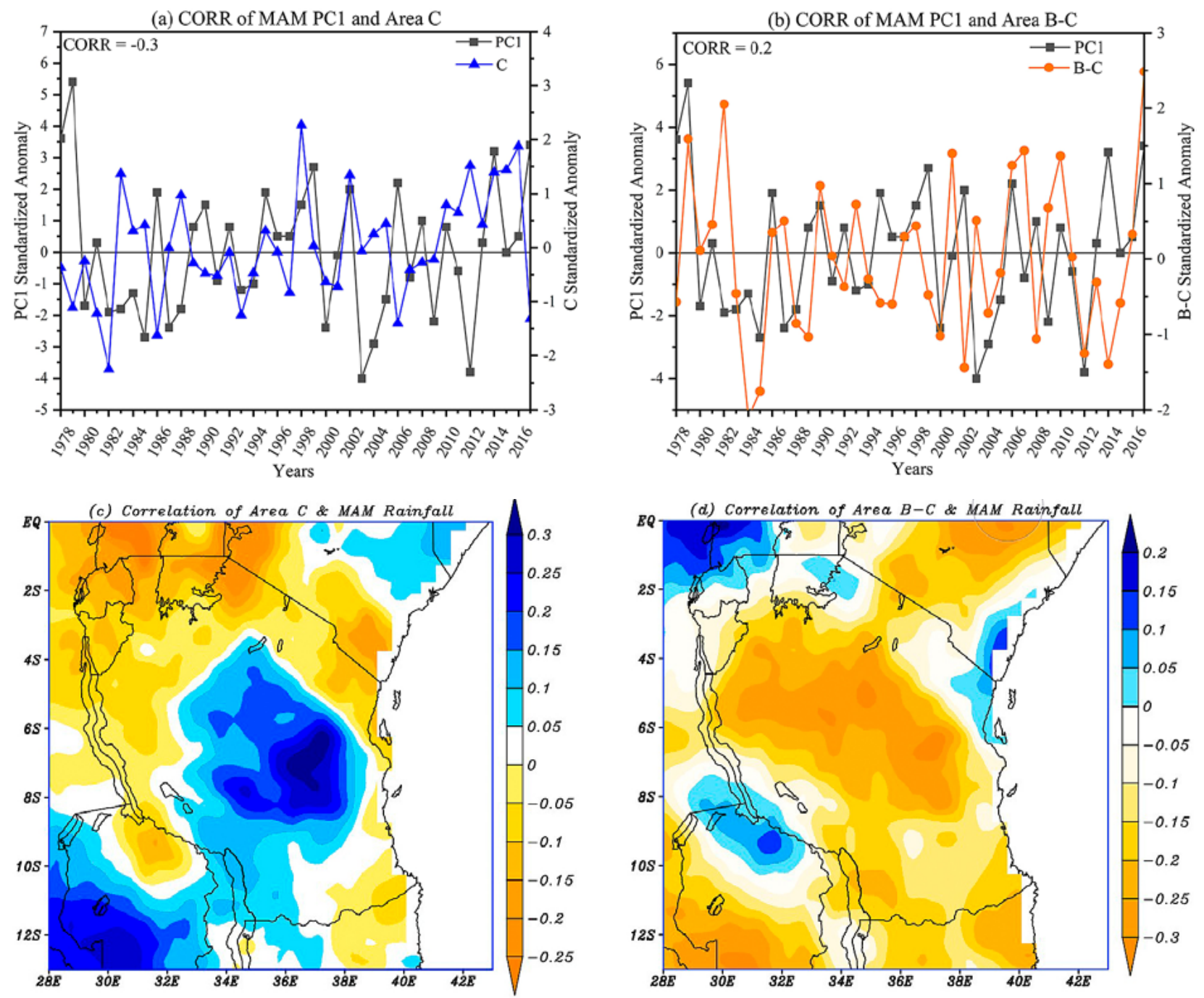

Figure 9. Time correlation between the time series of the first leading EOF mode (PC 1) and Sea surface temperature anomaly over (a) Region C in the southeast Indian Ocean (SEIO) and (b) The difference between region C and B (in the western Indian Ocean, WIO) during MAM season from 1978 to 2017. Correlations are significant at the $95 \%$ confidence level; Spatial map of correlation between observed MAM rainfall and SST anomalies in (c) region C (d) that of the difference between region $C$ and region $B$ 

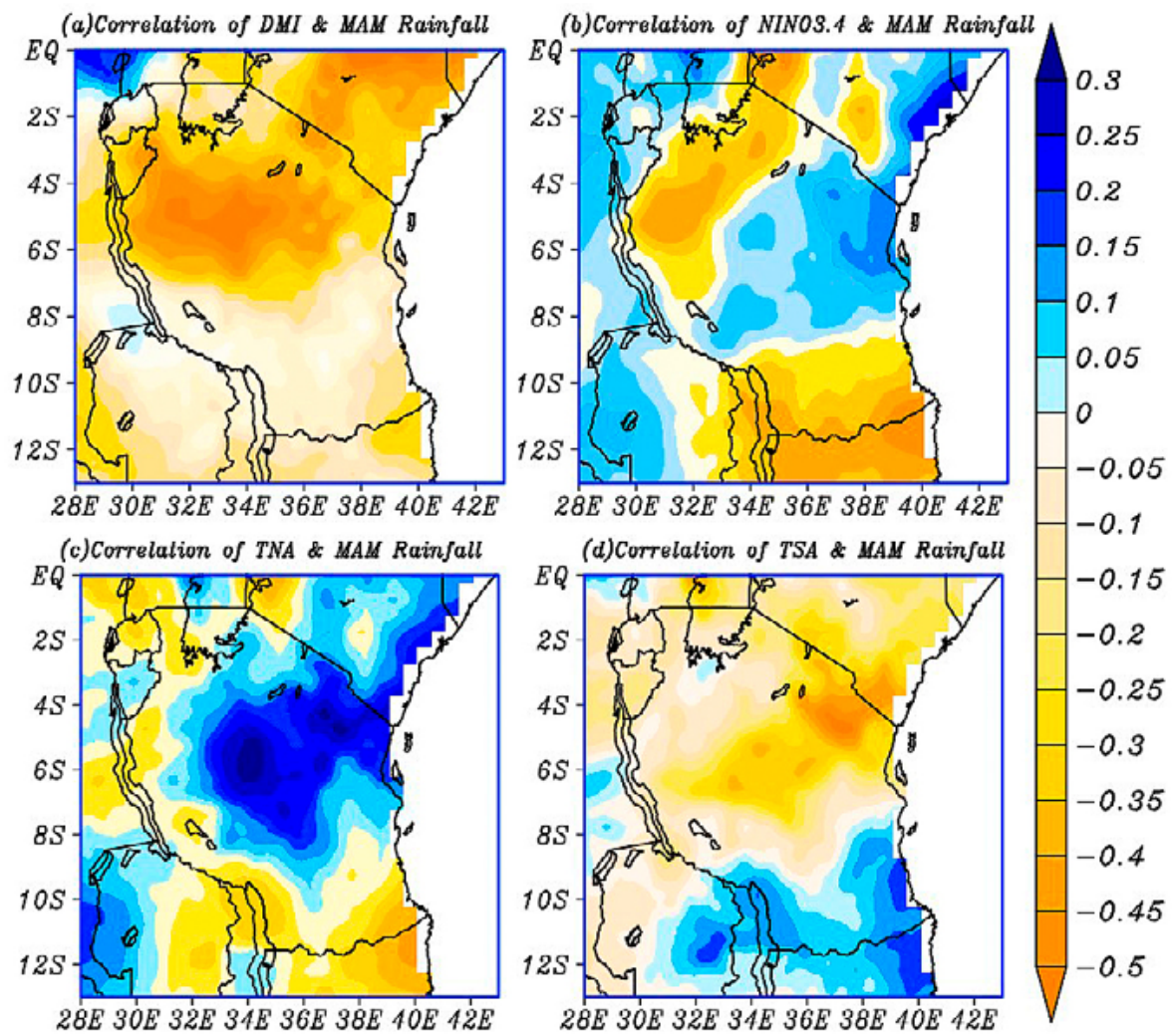

Figure 10. Spatial map of correlation between observed MAM rainfall and defined SST indices of (a) Dipole mode index (DMI); (b) Nino 3.4 index; (c) Tropical North Atlantic oscillation (TNA) index; and (d) Tropical South Atlantic oscillation (TSA) index from 1978 to 2017

ly to MAM rainfall with a strong negative correlation over the northern part. Nino 3.4 index is strongly positive correlated with rainfall over the eastern part (coast region) and strongly negative correlated with rainfall over the rest part of the country. Fig- ure $10 \mathrm{c}$ describes the strong negative correlation between TNA and rainfall over the coast and northeastern region and positive correlation between TSA and MAM rainfall was observed over the southern part of the country.

\section{Conclusion}

The study investigates inter-annual variability of March to May rainfall over Tanzania and its association atmospheric circulation anomalies by consideration periodic interval of 40 years (1978-2017). The domain experiences bimodal and unimodal rainfall regime during MAM and OND seasons in which MAM rainfall season contributes $43 \%$ of the total amount of rainfall the country receives annually. Climatologically, the southeastern, southern, and southwestern, east coast regions receive high amount of rainfall than other parts of country due to the concurrence of CAB and ITCZ. The rainfall shifts from south to north east and coast region from March to May due to northward movement of ITCZ which supports the previous studies that MAM rainfall over Tanzania is mainly influenced by movement of ITCZ (Clark et al., 2003).

The result from EOF1 accounts for $22.4 \%$ of total variance which is characterized by positive load- ing over eastern regions and negative loading over the central and Lake Zone. However, the first three EOF modes show $52.5 \%$ of total variance which imply that MAM season does not vary too much. Both corresponding time series of the first three leading modes describe that the variability of rainfall during MAM season is associated with the fluctuation of inter-annual and inter-decadal atmospheric weather phenomena. Composite analysis showed that during wet years, winds converge (diverge) at the lower (upper) level over the country, implying rising motion at lower level. These winds transport moist and unstable air from Congo basin (westerlies) and from Indian Ocean (south easterlies) and converge over the coast region. This convergence gives rise to vertical stretching and it is enhanced by ascending limb of Walker Circulation cell over the WIO, positive velocity potential anomalies observed over the region helps to trans- 
port moisture from Pacific Ocean towards the coast of Tanzania. MH weakens (strengthens) and moves further southward (northward) away from (towards) the continent, this allows (blocks) moisture to transfer towards the coast of Tanzania during wet (dry) years. Moreover, the climatology of stream function displays the teleconnection of tropical Pacific, Atlantic and Indian Oceans thus there is a close connection among these three Oceans. It was observed that during wet years, the WIO, central Pacific Ocean, east coast of Atlantic Ocean is relatively warm, the opposite sign was seen during the dry years. This illustrates the existing influence of these regions on rainfall variability during the MAM season over Tanzania.

MAM rainfall over the country is significantly positively correlated with SST anomalies over the central Pacific Ocean at the 95\% confidence level and is slightly positive with WIO. The spatial map of correlation between region $\mathrm{C}$ and MAM rainfall over Tanza- nia shows that the central part of the country is dominated by positive correlation while the rest parts of the country are negatively correlated with region C. This explains that when the WIO is relatively warmer than the SEIO, the coastal regions are positively correlated with MAM rainfall. DMI is negatively correlated to MAM rainfall with a strong negative correlation over the northern sector of the country. Nino 3.4 is strongly positively correlated with MAM rainfall over the eastern part (coast region) and strongly negatively correlated with MAM rainfall over the rest part of the country. The result describes the strong positive correlation between TNA and MAM rainfall over the central, coast, and northeastern region and a positive correlation between TSA and MAM rainfall was observed over the southern part of the country. Hence, this study provides updated scientific information which would be used for improving MAM rainfall season prediction.

\section{Acknowledgements}

The authors wish to express their sincere thanks to NCEP/NCAR, CRU and Tanzania Meteorological Agency (TMA) for their hard working in data preparations and make them available. We extend special thanks to Nanjing University of Information Science and Technology (NUIST) for creating a conducive research environment. The first author expresses his appreciations to China Government through CSC and World Meteorological Organization (WMO) for providing a full scholarship to pursue Master's Degree and make this research paper accomplished.

\section{Conflict of Interests}

The authors declare that there is no conflict of interest regarding the publication of this paper.

\section{References}

Black, E., Slingo, J., \& Sperber, K. R. (2003). An observational study of the relationship between excessively strong short rains in coastal East Africa and Indian Ocean SST. Monthly Weather Review, 131(1), 74-94. DOI:10.1175/1520-0493(2003)131<0074:AOSO TR>2.o.CO;2

Camberlin, P., \& Okoola, R. E. (2003). The onset and cessation of the "long rains" in eastern Africa and their interannual variability. Theoretical and $A p$ plied Climatology, 75(1-2), 43-54. DOI: 10.1007/ s00704-002-0721-5

Camberlin, P., \& Philippon, N. (2002). The East African March-May rainy season: Associated atmospheric dynamics and predictability over the 196897 period. Journal of Climate, 15(9), 1002-1019. DOI: 10.1175/1520-0442(2002)015<1002:TEAMMR>2.0. $\mathrm{CO} ; 2$
Camberlin, P., Moron, V., Okoola, R., Philippon, N., \& Gitau, W. (2009). Components of rainy seasons' variability in Equatorial East Africa: onset, cessation, rainfall frequency and intensity. Theoretical and applied climatology, 98(3-4), 237-249. DOI: 10.1007/s00704-009-0113-1

Clark, C. O., Webster, P. J., \& Cole, J. E. (2003). Interdecadal variability of the relationship between the Indian Ocean zonal mode and East African coastal rainfall anomalies. Journal of Climate, 16(3), 548554. DOI: 10.1175/1520-0442(2003)016<0548:IVOTR $\mathrm{B}>2.0 . \mathrm{CO} ; 2$

Dezfuli, A. K., \& Nicholson, S. E. (2013). The relationship of rainfall variability in western equatorial Africa to the tropical oceans and atmospheric circulation. Part II: The boreal autumn. Journal of Climate, 26(1), 66-84. DOI: 10.1175/ JCLI-D-11-00686.1 
Gamoyo, M., Reason, C., \& Obura, D. (2015). Rainfall Variability over the East African Coast. Theoretical and Applied Climatology 120(1):311-22. DOI: 10.1007/s00704-014-1171-6

Harris, I. P. D. J., Jones, P. D., Osborn, T. J., \& Lister, D. H. (2014). Updated high-resolution grids of monthly climatic observations-the CRU TS3. 10 Dataset. International journal of climatology, 34(3), 623642. DOI: $10.1002 /$ joc. 3711

Kabanda, T. A., \& Jury, M. R. (1999). Inter-annual variability of short rains over northern Tanzania. Climate Research, 13(3), 231-241.

Kabanda, T. (2018). Long-term rainfall trends over the Tanzania coast. Atmosphere, 9(4), 155.

Kalnay, E., Kanamitsu, M., Kistler, R., Collins, W., Deaven, D., Gandin, L., Iredell, M., Saha, S., White, G., Woollen, J., Zhu, Y., Chelliah, M., Ebisuzaki, W., Higgins, W., Janowiak, J., Mo, K. C., Ropelewski, C., Wang, J., Leetmaa, A., Reynolds, R., Jenne, R., \& Zhu, Y. (1996). The NCEP/NCAR 40-year reanalysis project. Bulletin of the American meteorological Society, 77(3), 437-472. DOI: 10.1175/1520-0477(1996)077<0437:TNYRP>2.0.CO;2

Katia, C., Nsiima, L., \& Zezza, A. (2012). Livestock and Livelihoods in Rural Tanzania. World Bank, FAO, AU-IBAR, ILRI and the Tanzania Ministry of Livestock and Fisheries Development (July):57.

Kijazi, A. L., \& Reason, C. J. C. (2005). Relationships between intraseasonal rainfall variability of coastal Tanzania and ENSO. Theoretical and applied climatology, 82(3-4), 153-176. DOI: 10.1007/s00704-0050129-0

Kijazi, A. L., \& Reason, C. J. C. (2009). Analysis of the 2006 floods over northern Tanzania. International Journal of Climatology: A Journal of the Royal Meteorological Society, 29(7), 955-970.

Kijazi, A. L., \& Reason, C. J. C. (2011). Intra-seasonal variability over the northeastern highlands of Tanzania. International Journal of Climatology, 32(6), 874-887. DOI: 10.1002/joc.2315

Koumare, I. (2014). Temporal/Spatial Distribution of Rainfall and the Associated Circulation Anomalies over West Africa. Pakistan Journal of Meteorology 10(20):1-11.

Koutsouris, A. J., Chen, D., \& Lyon, S. W. (2015). Comparing Global Precipitation Data Sets in Eastern Africa: A Case Study of Kilombero Valley, Tanzania. International Journal of Climatology 36(4):20002014. DOI: 10.1002/joc.4476

Krishnamurthy, V., \& Shukla, J. (2000). Intraseasonal and Interannual Variability of Rainfall over India. Journal of Climate 13(24):4366-77. DOI: 10.1175/1520-0442(2000)013<0001:IAIVOR>2.0.CO;2

Limbu, P. T. S., \& Guirong, T. (2019). Relationship between the October-December Rainfall in Tanza- nia and the Walker Circulation Cell over Indian Ocean. DOI: 10.1127/metz/2019/0939

Lorenz, E. N. (1956). Empirical Orthogonal Functions and Statistical Weather Prediction. Cambridge, Massachusetts.

Lyon, B. (2014). Seasonal Drought in the Greater Horn of Africa and Its Recent Increase during the MarchMay Long Rains. Journal of Climate 27(21):7953-75. DOI: 10.1175/JCLI-D-13-00459.1

Lyon, B., \& DeWitt, D. G. (2012). A Recent and Abrupt Decline in the East African Long Rains. Geophysical Research Letters 39(2):1-5. DOI: 10.1029/2011GL050337

Mafuru, K. B., \& Guirong, T. (2018). Assessing Prone Areas to Heavy Rainfall and the Impaction of the Upper Warm Temperature Anomaly during March-May Rainfall Season in Tanzania. Advances in Meteorology 2018. DOI: 10.1155/2018/8353296

Manatsa, D., Morioka Y., Behera, S. K.,. Matarira, C. H., \& Yamagata, T. (2014). Impact of Mascarene High Variability on the East African Short Rains. Climate Dynamics 42(5-6):1259-74. DOI: 10.1007/ soo382-013-1848-Z

Mapande, A. T., \& Reason, C. J. C. (2005). Interannual Rainfall Variability over Western Tanzania. International Journal of Climatology 25(10):1355-68. DOI: 10.1002/joc.1193

Mugalavai, E. M., Kipkorir, E. C., Raes, D., \& Rao, M. S. (2008). Analysis of Rainfall Onset, Cessation and Length of Growing Season for Western Kenya. Agricultural and Forest Meteorology 148(6):1123-35. DOI: 10.1016/j.agrformet.2008.02.013

Mutai, C. C., \& Ward, M. N. (2000). East African Rainfall and the Tropical Circulation/Convection on Intraseasonal to Interannual Timescales. Journal of Climate 13(22):3915-39. DOI: 10.1175/1520-0442(2000)013<3915:EARATT>2.0.CO;2

Ntwali, D., Ogwang, B. A., \& Ongoma, V. (2016). The Impacts of Topography on Spatial and Temporal Rainfall Distribution over Rwanda Based on WRF Model. Atmospheric and Climate Sciences o6(02):145-57. DOI: 10.4236/acs.2016.62013

Ogwang, B. A., Haishan, C., and Guirong, T. (2012). Diagnosis of September - November Drought and the Associated Circulation Anomalies Over Uganda. Pakstan Journal of Meteorology 9(17):11-24.

Onyutha, C. (2016). Geospatial Trends and Decadal Anomalies in Extreme Rainfall over Uganda, East Africa. Advances in Meteorology 2016:1-15. DOI: 10.1155/2016/6935912

Onyutha, C., \& Willems, P. (2016). Influence of Spatial and Temporal Scales on Statistical Analyses of Rainfall Variability in the River Nile Basin. $D y$ namics of Atmospheres and Oceans 77 (November 2016):26-42. DOI: 10.1016/j.dynatmoce.2016.10.008 
Van Der Schrier, G., Barichivich, J., Briffa, K. R., \& Jones, P. D. (2013). A ScPDSI-Based Global Data Set of Dry and Wet Spells for 1901-2009. Journal of Geophysical Research Atmospheres 118(10):4025-48. DOI: $10.1002 /$ jgrd.50355

Tyson, P. D., Garstang, M., Swap, R., Kallberg, P., \& Edwards, M. (1996). An Air Transport Climatology for Subtropical Southern Africa. International Journal of Climatology 16(3):265-91. DOI: 10.1002/(SICI)1097-0088(199603)16:3<265::AIDJOC8>3.0.CO;2-M

Wagesho, N., \& Claire, M. (2016). Analysis of Rainfall Intensity-Duration-Frequency Relationship for
Rwanda. Journal of Water Resource and Protection o8(07):706-23. DOI: 10.4236/jwarp.2016.87058

Williams, A. P., \& Funk, C. (2011). A Westward Extension of the Warm Pool Leads to a Westward Extension of the Walker Circulation, Drying Eastern Africa. Climate Dynamics 37(11):2417-35. DOI: 10.1007/ s00382-010-0984-y.

Zorita, E., \& Tilya, F. F. (2002). Rainfall Variability in Northern Tanzania in the March-May Season (Long Rains) and Its Links to Large-Scale Climate Forcing. Climate Research 20(1):31-40. 